\title{
LATIN AMERICAN
}

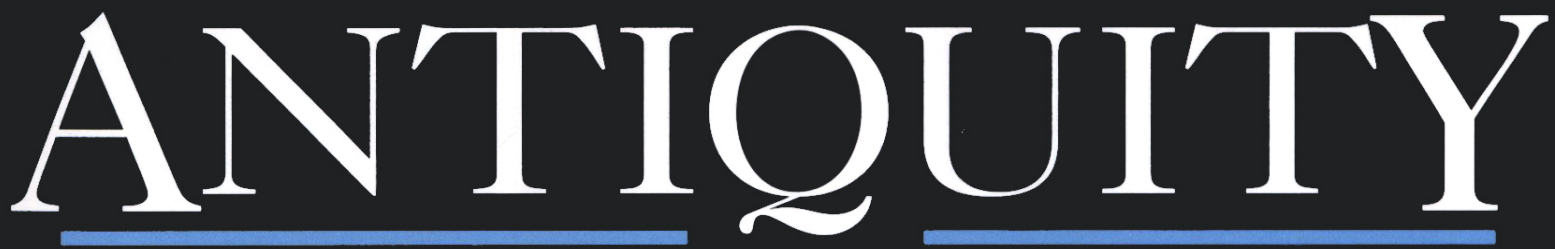

$\begin{array}{llllll}\text { VOLUME } & 13 & \text { NUMBER } & 1 & \text { MARCH } & 2002\end{array}$
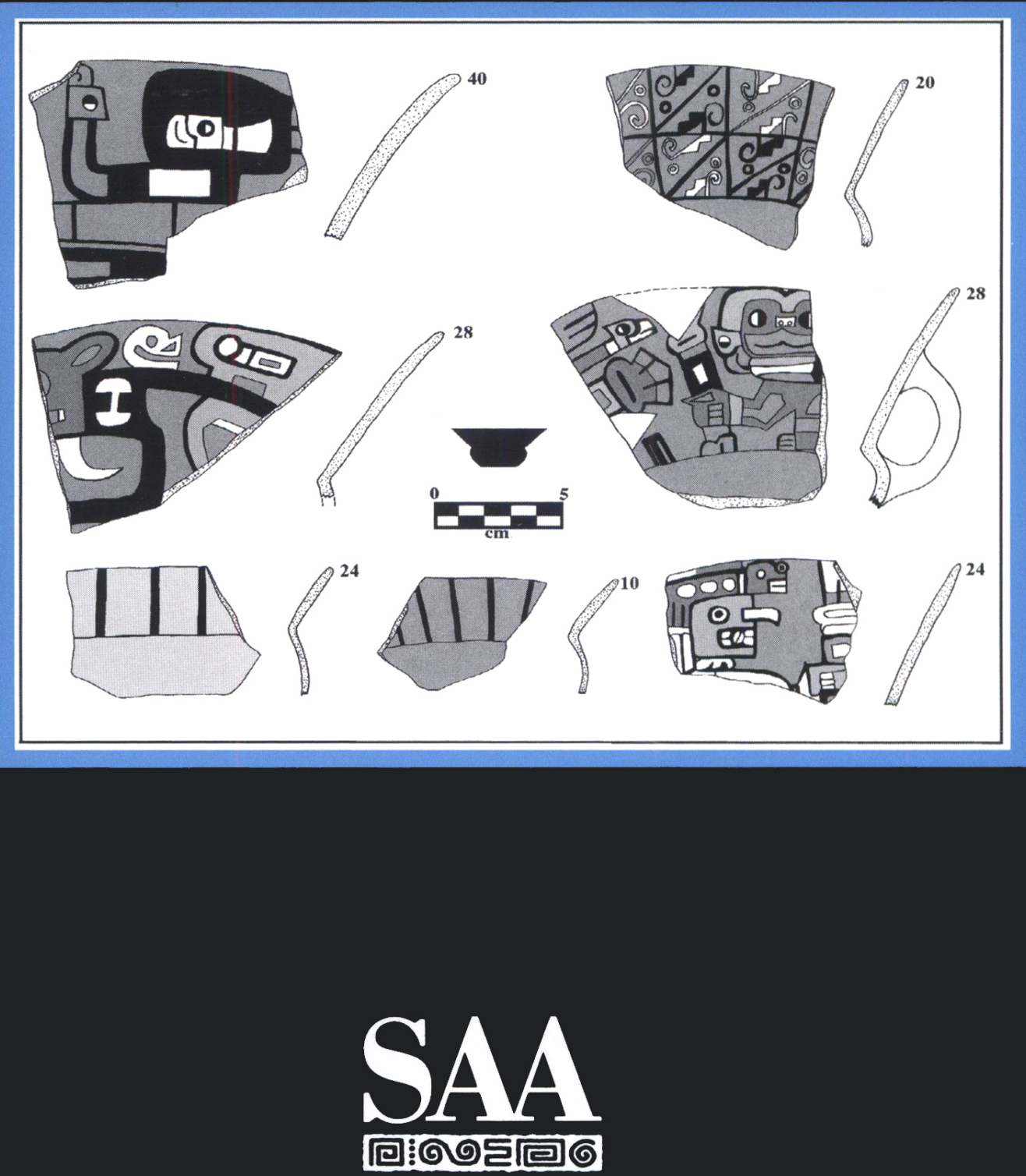

SOCIETY FOR AMERICAN ARCHAEOLOGY 
Coediror: SUZANNE K. FISH, Arizona State Museum, University of Arizona, Tucson, Arizona 85721-0026; Email: latamaq@email.arizona.edu; Telephone: 520-621-4794; Fax: 520-621-2976

Coeditor: MARIA DULCE GASPAR, Museo Nacional Universidade Federal do Rio de Janeiro, Brasil; Email: mgaspar@alternex.com.br; Telephone and Fax:011-55-21-2205-7095

Editorial Assistants: BRIAN MCKEE and BRUCE BACHAND, Latin American Antiquity Editurial Office, Arizona State Museum, University of Arizona, Tucson, Arizona 85721-0026. Email: latamay @email.arizona.edu; Telephone 520-621-4794; Fax: 520-621-2976

Managing Editor: JOHN NEIKIRK, Society for American Archaeology, 900 Second Street NE. Suite 12, Washington, DC 20002-3557 Email: john_neikirk@saa.org Telephone (202) 789-8200

Associate Editor for Reviews and Book Notes: K. ANNE PYBURN, Department of Anthropology. Indiana University, Student Building 130, Bloomington, IN 47405; Email: apyburn@indiana.edu; Telephone: (812) 855-8162; Fax: (812) 855-4358

\section{BOARD OF EDITORS FOR LATIN AMERICAN ANTIQUITY}

TOM D. DILLEHAY, Department of Anthropology, University of Kentucky, Lexington, KY 40504

ROBERT D. DRENNAN, Department of Anthropology, University of Pittsburgh, 3H FQ, Pittsburgh, PA 15260

JOYCE MARCUS, Museum of Anthropology, University of Michigan, University Museums Building, 1109 Geddes Avenue, Ann Arbor, MI 48109-1079

ELSA M. REDMOND, Department of Anthropology, American Museum of Natural History, Central Park West at 79 th St., New York, NY 10024

CHARLES STANISH, Department of Anthropology, Hershey Hall, UCLA, Los Angeles, CA 900\%)

IRMHILD WÜST, Universidade Federal de Goiás, Av. T15/C-263 Ed. Teodoro, Apto. 602, Nova Suiçal, 74280. 260 Goiânia-GO, Brazil

\section{EDITORIAL ADVISORY COMMITTEE FOR LATIN AMERICAN ANTIQUITY}

ELIZABETH BRUMFIEL (Department of Anthropology and Sociology, Albion College, Albion, MI)

LUIS JAIME CASTILLO BUTTERS (Pontificia Universidad Católica del Perú, Lima, Perú)

GARY M. FEINMAN (Field Museum of Natural History, Chicago)

PATRICIA FOURNIER (Escuela Nacional de Antropologia, Division de Posgrado, Periférico Sur y Zapotal, Delegacion Tlalpan, México)

CRISTOBAL GNECCO (Departamento de Antropología, Universidad de Cauca, Popayan, Cauca, Colombia)

LINDA MANZANILLA (Instituto de Investigaciones Antropológicas, Universidad Nacional Autónoma de México, México D.F.)

RAMIRO MATOS MENDIETA (National Museum of the American Indian, Smithsonian Institution. Research. Branch, Bronx, NY)

EMILY McCLUNG de TAPIA (Instituto de Investigaciones Antropológicas, Universidad Nacional Autónoma de México, México)

BEN A. NELSON (Department of Anthropology, Arizona State University, Tempe, AZ)

PATRICIA PLUNKET (Departamento de Antropología, Universidad de las Américas-Puebla, México)

GUSTAVO POLITIS (División Arqueología, Facultad de Ciencias Naturales y Museo, La Plata, Argentina)

K. ANNE PYBURN (Department of Anthropology, Indiana University, Bloomington, IN)

JEFFREY QUILTER (Dumbarton Oaks, Washington, DC)

NELLY ROBLES GARCIA (Centro Regional de Oaxaca, Instituto Nacional de Antropología e Historia, Oaxaca, México)

ANNA ROOSEVELT (Field Museum of Natural History, Chicago)

JEREMY A. SABLOFF (University Museum, University of Pennsylvania, Philadelphia)

SILVIA SALGADO GONZALEZ (Universidad Politecnica de Nicaragua, ICIDRI)

KATHARINA J. SCHREIBER (Department of Anthropology, University of California at Santa Barbara)

CONSTANTINO M. TORRES (Visual Arts Department, Florida International University, Miami)

ERIKA WAGNER (Instituto Venezolano de Investigaciones Cientifícas, Caracas, Venezuela)

Latin American Antiquity (ISSN 1045-6635) is published quarterly in March, June, September, and December by the Suciety for American Archaeology, 900 Second Street, N.E., Suite 12, Washington, DC 20002-3557. The journal is one of two offered as a benefit of individual membership. Subscription rates are $\$ 130.00$ for institutions residing in Australia, Bahrain, Bermuda, Canada, Cyprus, Israel, Japan. Korea, Kuwait, Libya, New Caledonia, New Zealand, Qatar, Saudi Arabia, Sultanate of Oman, Singapore, Taiwan, Thailand, United States, or western Europe; \$50.00 for members in these countries who already receive the society's other journal as a membership benefit; and \$,3,00 for members and institutions in Latin America or any other country not listed above. To subscrihe. change an address, or order back issues, please write to the Society for American Archaeology at the above address. Prepayment is required, payable in U.S. funds. Latin American Antiquiry is not available for exchange. Claims for nonreceipt and for damaged copies must be made within 90 days (U.S.) or 180 days (non-U.S.) of the publication date for free replacement. Non-U.S. deliveries cannot be guaranted: nonU.S. members and subscribers may purchase replacement copies at a $20 \%$ discount. Latin American Amiquiry is typesel by Oakland Street Puhlishing, Arlington, Virginia, and printed by IPC, St. Joseph, Michigan.

Periodicals postage paid at Washington, D.C.. and additional mailing offices. POSTMASTER: Send address changes to Latin American Antiquity, c/o Society for American Archaeology, 900 Second Street, N.E., Suite 12, Washington, DC 20002. 


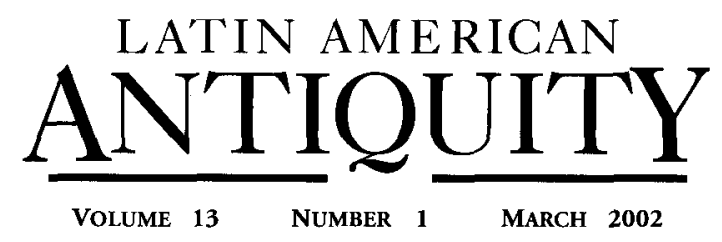

\section{ARTICLES}

3 Imperial and Social Relations in Postclassic South-Central Veracruz, Mexico Christopher P. Garraty and Barbara L. Stark

35 Out of Many, One: Style and Social Boundaries in Tiwanaku John Wayne Janusek

\section{REPORTS}

63 An Early Classic Colonnaded Building at the Maya Site of Blue Creek, Belize W. David Driver

85 Spouted Vessels and Cacao Use Among the Preclassic Maya Terry G. Powis, Fred Valdez, Jr., Thomas R. Hester, W. Jeffrey Hurst, and Stanley M. Tarka, Jr.

107 Description and Method of Exploitation of the Alca Obsidian Source, Peru Justin Jennings and Michael D. Glascock

\section{REVIEWS}

119 The Cambridge History of the Native Peoples of the Americas. Volume III, South America, part 2, edited by Frank Salomon and Stuart B. Schwartz

Thomas Cummins

120 Precolumbian Gold: Technology, Style, and Iconography, edited by Colin McEwan Clemencia Plazas

121 Formativo Sudamericano, una revaluación: Ponencias presentadas en el Simposio Internacional de Arqueología Sudamericana, Cuenca-Ecuador, 13-17 de enero de 1992: Homenaje a Alberto Rex González y Betty J. Meggers, edited by Paulina Lederberger-Crespo Warren DeBoer

122 Ethnoarchaeology of Andean South America: Contributions to Archaeological Method and Theory, edited by Lawrence A. Kuznar

Chad Gifford

124 Place of the Lord's Daughter: Rab'inal, Its History, Its Dance-Drama, by Ruud van Akkeren Timothy Smith 
125 Les au-delàs aztèques, by Nathalie Ragot

Guilhem Olivier

126 Moqueries et métamorphoses d'un dieu aztèques: Tezcatlipoca, le "Seigneur au miroir fumant," by Guilhem Olivier

Dominique Raby 